\title{
Similarities and Differences between Tom and Gatsby in The Great Gatsby
}

\author{
Chenye Wang \\ College of Foreign Languages and Literature, Wuhan University, Wuhan Hubei, 430072, China
}

Key words: Similarities, Differences, Tom, Gatsby.

\begin{abstract}
The Great Gatsby, one of Francis Scott Key Fitzgerald's representative works, has been regarded as his prestigious masterpiece for several decades. In this novel, the two contradictory characters, Tom and Gatsby, are described specifically and vividly. Being the protagonist in the novel, Gatsby is such an attractive and important figure that has been discussed and studied for times. However, Tom, as a well-depicted antagonist, is also a quite significant role and has been sometimes neglected by readers and scholars. Therefore, this essay will focus on the comparison and contrast between Tom and Gatsby in this masterpiece. And from this perspective, the reason why Daisy insists on being with Tom rather than Gatsby will also be studied and demonstrated in the following.
\end{abstract}

\section{Introduction}

In the novel, Tom and Gatsby are two different and contradictory figures from which the intense conflicts are derived. Tom was born in a rich family where there was abundant wealth left for him and his future life. However, on the contrary, Gatsby was born in a poor family with low social status. Via his persistent exertion and struggling, he earned a sizeable amount of wealth. The comparison and contrast above haven't been studied specifically by former scholars. Barbara Will has studied Gatsby and the obscene word in 2005. Zhao Hongwei has studied the definition of American Dream in 2003. Bao Lei has focused on the depiction of characters in the novel in 2012. From the comparison and contrast, the fact that money may ruin people's senses and minds is well-invited in the novel. Humanity becomes the sacrifice of this appalling tragedy which is engendered by money and vanity. In showing this tragic scene, the two characters surely have some similarities and differences, which will be demonstrated in the following.

\section{Similarities between Tom and Gatsby}

\section{Pursuit for money and vanity}

Although Tom and Gatsby are from different family backgrounds and social status, they have one thing in common, that is the pursuit for money and vanity. Both of them are quite and extremely addicted to the temptation derived from money and vanity, no matter how far the distance is between themselves and those dreams. In their minds, money is the symbol of fame, reputation, power and status which will more or less satisfy their inner vanity. As for Tom, he inherits lots of money without knowing to cherish them but continuing his extravagant behaviors. He may think that he certainly deserves the money which will remain eternal, therefore, he always shows off in front of others via his heritages which do not actually belong to him. Money becomes a tool for him to show off and satisfy his vanity. As to Gatsby, he endeavors hard to pursue his dreams for money and status, and he thinks money will solve almost everything if he himself can earn enough. In this way, Gatsby is also restrained and mislead by his pursuit for money. In general, the corruption of humanity made by money and vanity cannot only be seen from Tom and Gatsby, but also from other common people. The era of money decides their outrageous personalities and behaviors. 


\section{Exploitation and conquer}

In the novel, it is obvious that both Tom and Gatsby gain their money and treasure via exploitation and conquer. Tom inherited his family's money and treasure without using even a little bit of his strength and ability. Similarly, Gatsby retained his money and treasure via smuggling, which would be viewed as a crime. Therefore, from this perspective, we can clearly see that both of them are fond of exploitation and conquer which is considered as the representative of American Dream. The strong passion about exploitation and conquer has been immersed into the blood of every Americans, which leads America to a problematic society. Although they can bring themselves about substantial money and vanity, the heart, mind and mentality will become rotten and decaying as time elapses.

\section{Differences between Tom and Gatsby}

\section{Social background and status}

Tom and Gatsby are from totally different social backgrounds and status. Gatsby has ever joined in the army in the First World War, and he is from an impoverished family background and lower-class. However, Tom Buchanan was born in a family of millionaires and middle-class which left him abundant wealth to inherit. These differences in social background and status decide their humanity, behaviors and manners, attitudes to love and senses of wealth.

\section{The way of acquiring wealth}

As is known to all, both Tom and Gatsby have acquired substantial wealth in their lives. However, their ways of acquiring wealth are totally different. Tom Buchanan becomes extremely affluent by inheriting wealth of his family. In other words, Tom obtains such wealth without even a little bit of hard work. On the contrary, like Gatsby, many poor guys start working hard and try everything in their power to accumulate their wealth, in order to enhance the social status. In their minds, wealth is the paramount thing which symbolizes success and brings about dignity, status and power. Unlike Tom who is too lazy and extravagant to realize the authentic source of wealth, Gatsby exerts himself to pursue his dream of wealth. No matter how poor or humid he has ever been, and no matter how far the distance between him and his expected wealth, Gatsby always accelerates his speed of pursuit and perseveres all through the process. Therefore, he finally succeeds in his dream of wealth.

\section{The attitude towards wealth}

In the novel, Tom and Gatsby have different attitudes towards wealth. As for Tom, his substantial wealth brings him about affluent life, strong power and high social status. However, such sizeable wealth gradually misleads him into the golden and obscure dreams where there are filled with hypocrisy, extravagance and arrogance. Although Tom inherits such wealth, he chooses to arrogantly show off and be exceedingly extravagant, hypocritical, which eventually makes him isolated and failed. However, as to Gatsby, he regards the wealth as his strong motivation of pursuing his dream. $\mathrm{He}$ is in the position to look ahead and go ahead and fight for the future persistently, because of the attraction and guide from the future wealth. In this way, Gatsby develops some of his great qualities in the process of fighting for success, which is totally different from Tom's lazy enjoyment on his present wealth. In a word, while Gatsby is persistent in improving himself, Tom has forgotten the fact that wealth is originated from society, and he has also forgotten that he himself should be a working man.

\section{The attitude towards love}

From the perspective of their attitudes towards love, both men have something quite different as well. In Tom's mind, actually, he loves himself more than he loves Daisy. He supposes that it is natural and normal for him to acquire Daisy and her love, because of his fascinating social status and substantial wealth. Therefore, he falls into the trap of deep narcissism, which makes him pay less attention to Daisy. As for him, wealth is not only the basis of steady love, but also the only reliable thing in love. In contrast, Gatsby shows a different attitude. His love towards Daisy is really pure and 
from the bottom of his heart. He loves this lady, but he knows her high social status quite clearly, so he tries everything in his power to change and improve himself to satisfy Daisy. Although the love is also built on wealth and Daisy herself is seriously indulged in fame and wealth, we can see that Gatsby pursues his lover in a quite honest and bright way, and never gives up during the process of pursuit, even if he will sacrifice one day.

\section{Self-cultivation}

Apparently, Tom and Gatsby have different levels of self-cultivation. Tom is fond of and also good at sports. His muscle shows that he possesses a quite strong and powerful body. However, those features bring him about violent inclination. Tom is more like an immature guy who doesn't have wise mind and brain. He is prone to use physical actions or violent behaviors to solve problems. On the opposite, Gatsby is described as a wise and persevering guy who has clear mind and target. He will read a beneficial book or magazine every week and diversify his knowledge, which eventually makes him become intelligent in upper-class. No matter how tough and complicated the society is, Gatsby never hesitates in pursuing his dream and he always maintains a positive and optimistic attitude towards the present and future.

\section{The reasons why Daisy chose to stay with Tom}

Throughout the novel, Tom is portrayed in the extremely negative light, but Daisy still chooses to remain with him instead of leaving him for Gatsby. Here are the possible explanations.

First, Daisy is a quite realistic lady who is only fond of and interested in materials and wealth. However, as for the fact of both men's wealth, Tom's wealth is legally inherited, while much of Gatsby's wealth is illegally smuggled, although he tries a lot in pursuing Daisy and his future. This fact is investigated and discovered by Tom and then he tells Daisy all about it. The sudden news makes Daisy feel uneasy and depressed. She finds that Gatsby's wealth is not as stable and dependable as she has ever expected.

Next, the most direct reason is that Daisy drives her car and kills Tom's mistress. The frightened Daisy daren't tell Tom the truth. Therefore, she chooses to shift the blame on Gatsby, in order to protect herself. At this time, Daisy doesn't love Gatsby at all because she only wants to protect her own life and stay with Tom to live a stable and also luxurious life.

Then, Daisy has ever expressed that she wants to elope with Gatsby because she admires Gatsby's improvement and present wealth. However, this request is refused by Gatsby because Gatsby wants to marry Daisy in an honest and bright way rather than elope with each other. This choice, to some extent, makes Daisy feel disappointed.

Finally, the most important reason may be the gap between social strata. Both Tom and Daisy are from aristocratic class, while Gatsby is originally from lower class and he is more like an upstart whose wealth is not stable and reliable at all. At that period of time, the differences and gap between social strata were quite striking and such conventions shouldn't be violated. We can imagine that if Daisy marries Gatsby, she will be commented by the society which will bring about negative influences to them. And actually, Tom and Daisy have already got their child, which will also let Daisy be in a difficult dilemma. Hence, Daisy chooses to live with Tom after overall making these thoughts and choices.

\section{Conclusion}

Tom Buchanan and Gatsby surely have some profound similarities and differences in the novel. One is the representative of American middle-class, and the other is the representative of someone who improves himself from lower-class to a prestigious celebrity. Both of them have some noticeable and special features which may reflect the development of American society. In fact, their similarities and differences haven't been discussed and studied entirely nowadays, there are still some areas waiting for scholars to further study and explore. 


\section{References}

[1] Bao Lei. A Unique Hero: The Characterization in The Great Gatsby. Overseas English, 2012(8).

[2] Burnam, T. A Re-Examination of The Great Gatsby. College English, 1952.

[3] Fitzgerald, F. Scott. The Great Gatsby. Penguin Classics, 1994.

[4] Wang Weiqin. An Analysis of American Dream in The Great Gatsby. Movie Literature, 2013(1).

[5] Will, Barbara. The Great Gatsby and the obscene word. College Literature, West Chester University, 2005.

[6] Yang Huiqun. An Analysis of Francis Scott Key Fitzgerald's The Great Gatsby. Journal of Jiangsu Radio \& Television University, 2002(5).

[7] Zhao Hongwei. Disillusionment of Gatsby's American Dream from Perspective of Society---Analysis of The Great Gatsby. Journal of Harbin University, 2003(6). 